TITLE:

\title{
Effect of maturation on nerve excitability in an experimental model of threshold electrotonus(Abstract_要旨 )
}

\section{$\operatorname{AUTHOR}(\mathrm{S})$ :}

Yang, Qing

\section{CITATION:}

Yang, Qing. Effect of maturation on nerve excitability in an experimental model of threshold electrotonus. 京都大学, 2000, 博士(医学)

ISSUE DATE:

2000-03-23

URL:

http://hdl.handle.net/2433/180851

RIGHT: 


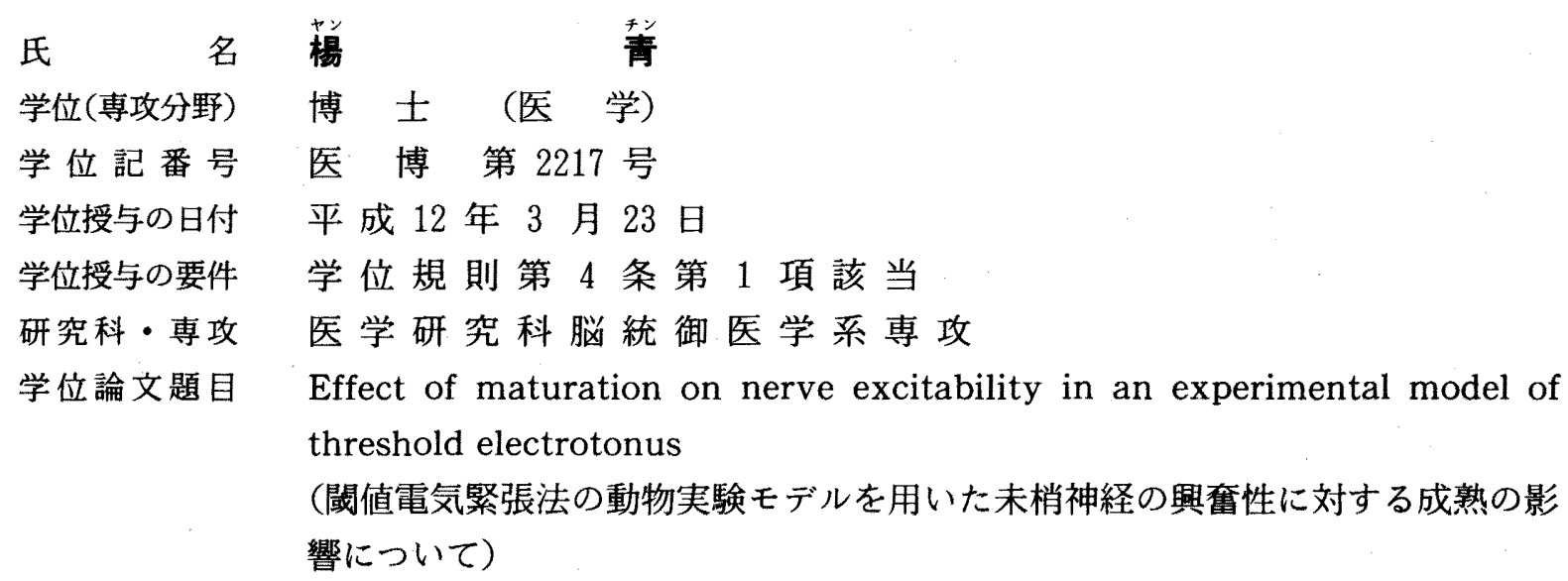

論文調査委員教授大森治紀教授井出千束教授柴崎浩

\section{論 文 内 容 の 要 旨}

Threshold electrotonus 法（閾値電気緊張法；TE 法）は，1988 年に Bostock らにより考案された検査法で，生体におい てヒトの末梢神経の膜電位変化や $\mathrm{K}+$ チネルなどの機能を, 簡単に非侵襲的に評価することができる方法である。従来の 神経伝導検查は, 伝導速度, 伝導ブロック, 伝導している神経線維数を調べるあのであり, それらのあたらす情報は神経線 維そのものよりも, それを取りまく䯑鞘の機能を, より多く反映している。従って, TE 法は従来の神経伝導速度を補完し, 神経線維そのもの機能を臨床的に知る有力な検査法となることが期待される。

最近, TE 法の臨床応用がなされ, 筋萎縮性側索硬化症や糖尿病性ニューロパチー, 中毒性ニューロパチー, LewisSumner 症候群, monomelic amyotrophy with spinal hemiatrophy（MASH）の患者に扔いて, その異常が報告されてき たが, それらの解积については未だ不明な部分が多い。そこで動物を用いて TE 法でみられる变化の意味する生理学的意義 を調べることとし，ラットの尾神経を用いた TE 法の実験モデルを考案しだ。本方法を用いて，ラットの成長による末梢神 経軸索機能の変化を検討した。

『対象之方法』

(1) 対象:

Wistar rat $90 \mathrm{~g}$ から $650 \mathrm{~g}$ までの 77 匹を用いた。ヒトの結果と比較するため健常成人 8 人（男性 6 人）について TE 法を 用いて記録を行った。

(2) 実験的 TE 法の記録:

Wistar ratにペントバルビタールを腹腔内注射して麻酔し，その尾部を $35^{\circ} \mathrm{C} に$ 保ったゴム製の台の上に置く。尾の近位 部に刺激電極を置き，その末梢側 $6 \mathrm{~cm}$ に記録用針電極を挿入し，尾部に $20 \% ， 40 \%$ の脱分極及び過分極の条件刺激（100 $\mathrm{ms}$ ）を与えて, 最大 CMAP 振幅の $30 \%$ の振幅を得るために必要な試験刺激電流を計測した。試験刺激は, $0 \mathrm{ms〜} 100 \mathrm{~ms}$ までの条件刺激中及びその後の $100 \mathrm{~ms}$ の計 $200 \mathrm{~ms}$ の間に，刺激夕イミングを順次ずらしながら与えた。

(3) TE 記録の解析 :

Fast $\mathrm{K}+$ チャネルの機能の評価として, 40\% 脱分極時の $10 ２ 0 \mathrm{~ms}$ 部分（TEd 10－20）の閾値变化の平均を, slow K+ チャネルの機能の評価として, 40\% 脱分極時の $90 \sim 100 \mathrm{~ms}$ 部分（TEd 90-100）の閾值变化の平均から TEd 10-20を減 じたあのを, また䯣節間抵抗 $(R)$ の評価として, $40 \%$ 過分極時の $10 \sim 20 \mathrm{~ms}$ 部分 (TEh 10-20) の閾値变化の平均を用い た。それらの値と日齢の指標となる体重との相関を統計学的に分析した。

(4) 薬理学実験 :

Wistar rat 15 匹 (90〜 $100 \mathrm{~g} ： 5$ 匹，200〜 310 g：5匹，440〜650 g：5匹）を用いて薬理学実験を行った。6匹のラッ 
トに fast $\mathrm{K}+チ$ ネルのブロッカーである 4 -aminopyridine （4-AP） を腹腔内に投与し， 9 匹には，内向き較正電流 （inward rectifier）のブロッカーである $\mathrm{CsCl}$ を腹腔内に投与，20 分後に $\mathrm{TE}$ の記録を行った。

『結果』

（1）成熟したラットの TE 記録は，ヒトの TE 記録とよく似ていたが，閾値变化はヒトよりあ少なかった。

（2）䯣節部 fast $\mathrm{K}+$ チャネルは, 成長に伴って体重 $330 \mathrm{~g}$ まで発現の增加が認めたが, $330 \mathrm{~g}$ 以降, 突然低下し, $400 \mathrm{~g}$ 以 降は安定していた。

（3） slow $\mathrm{K}+$ チャネル活性は成長に伴なう有意の変化を示さなかった。

（4）㟘道節間抵抗 (R) は成長に伴って軸索径の增大が扔こるために次第に減小してくるが, 体重 $330 \mathrm{~g}$ 以降は安定してた。 潜時も同様の変化がみられた。

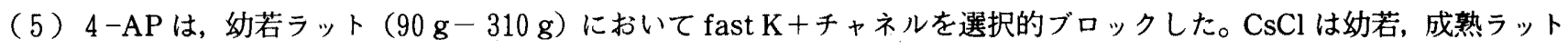
の内向き較正電流（inward rectifier）を同様にブロックした。

『結論と考察』

（1）幼若ラットでは加秢とともに fast $\mathrm{K}+チ$ ネルの䯣節での発現が増加するが, 成熟ラット（400 g- $650 \mathrm{~g} ）$ では, 䯣 節の脱分極によっても fast $\mathrm{K}+$ チャネルは活性化されなくなる。これは骾鞘の完成に伴って傍髄節部の fastK+チャネルが 機能的に隔絶されるためと考えられた。

（2）成熟ラット（400 g-650 g) では，TE法での記録では体重に伴なう変化がみられなかった。

（3）上記の結果から TE 法を用いてラットの群間比較や経時的变化の観察を行う場合には, $400 \mathrm{~g}$ 以上のラットを使用す る必要がある。

（4）TE 法はfastK+チャネル，内向き較正電流，軸索と髅鞘のケーブル特性を反映することが実験的に証明された。

（5）TE 法の臨床応用はまだ始まったばかりであり，今後様々な末梢神経障害の検查に利用されるだけでなく，病態解明 や治療法の開発に貢献していくものと考えられる。その解釈にあたってラットのモデルは重要である。

\section{論文害查の結果の要旨}

Threshold electrotonus 法 (閥値電気緊張法; TE 法) は, 生体においてヒトの末梢神経軸索の膜電位変化や K+チャネ ルなどの機能を短時間に非侵簑的に評価する方法であり，臨本的に神経線維軸索機能を検查する有力な手段となることが期 待されている。本研究では，ラットの尾神経を用いた TE 法の実験モデルを作成し，ラットの成長に伴う末梢神経軸索機能 の変化を検討した。ウィスターラット77匹を用いて，尾の近位部に刺激電極を置き，その末梢側 $6 \mathrm{~cm}$ に記録用針電極を挿 入し，尾部に $20 \%$ および $40 \%$ の脱分極及び過分極の条件刺激（100 ms）を与えて, 最大活動電位の $30 \%$ の振幅を得るため に必要な試験刺激電流を計測した。TE記録の解析として fast $\mathrm{K}+$ チャネルの機能, slow $\mathrm{K}+$ チャネルの機能, およびそれ

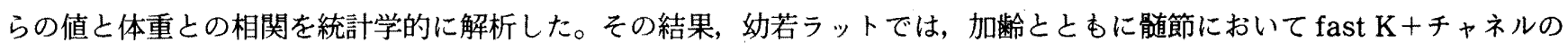
発現が増加するが，体重 $350 \mathrm{~g}$ を境界として，䯣節の脱分極によっても fast $\mathrm{K}+$ チャンルは活性化されなくなった。成熟 ラットでは, TE の記録では体重に伴なう変化がみられなかった。従って, TE 法を用いてラットの群間比較または経時的変

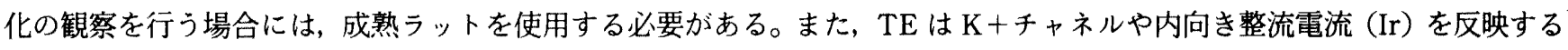
ことが実験的に示された。

以上の研究は, TE 法を末梢神経障害の検查に応用するに当ってその理論的裏付けを与え, その病熊の解明と治療法の開 発に寄与するところが多い。

したがって, 本論文は博士 (医学) の学位論文として価值あるものと認める。

なお，本学位授与申請者は，平成 12 年 2 月 2 日実施の論文内容とそれに関連した試問を受け，合格と認められたものであ る。 